\title{
Multiple Myeloma with Prominent Auer Body Formation in Granulocytes
}

Junichiro Takano, Takako Kitahara, Shotaro Hagiwara* and Akiyoshi Miwa

Division of Hematology, Internal Medicine, National Center for Global Health and Medicine, Tokyo, Japan

*Corresponding author: Shotaro Hagiwara, Division of Hematology, Internal Medicine, National Center for Global Health and Medicine, Tokyo, Japan, Tel: +81-3-3202-7181; E-mail: shagiwar@hosp.ncgm.go.jp

Rec date: Oct 28, 2014, Acc date: 03 November, 2014, Pub date: 5 November, 2014

Copyright: (c) 2014 Shotaro Hagiwara, This is an open-access article distributed under the terms of the Creative Commons Attribution License, which permits unrestricted use, distribution, and reproduction in any medium, provided the original author and source are credited.

Keywords: Multiple myeloma; Cytogenetics; Auer body formation in granulocytes; Thrombocytopenia

\section{Clinical Image}

A 57-year-old man with IgG, ISS stage II multiple myeloma with normal cytogenetics was treated with vincristine/adriamycin/ dexamethasone induction followed by autologous hematopoietic stem cell transplantation and achieved a very good partial response. The patient relapsed 4.5 years later and received bortezomib/ dexamethasone treatment, which conferred a very good partial response once again. After 3 years, his $\mathrm{M}$ protein level showed a rapid increase to $7.9 \mathrm{~g} / \mathrm{dl}$ for a month. He also developed anemia, thrombocytopenia (white blood cell count, 5600/l; hemoglobin, 7.3 $\mathrm{g} / \mathrm{dl}$; platelet count, 9000/l), acute kidney injury, and acute liver failure. Relapse of multiple myeloma was confirmed by bone marrow biopsy, which showed $55.8 \%$ clonal plasma cells with complex karyotype abnormality including addition of 1q21, and fluorescence in situ hybridization revealed deletion of p53. Notably, neutrophils harboring prominent Auer rods were found in his bone marrow. Several pseudoPelger-Huet anomaly cells were observed, however myeloblasts were only $0.5 \%$; there was no myeloblast with Auer rods. Also mild dyserythropoiesis and few abnormal megakaryocytes were observed (Figure 1)

Although the mechanism of Auer rod formation in this case is uncertain, myeloma-related damage of the bone marrow microenvironment or dysregulation of hematopoietic stem cells may have played a role [1].

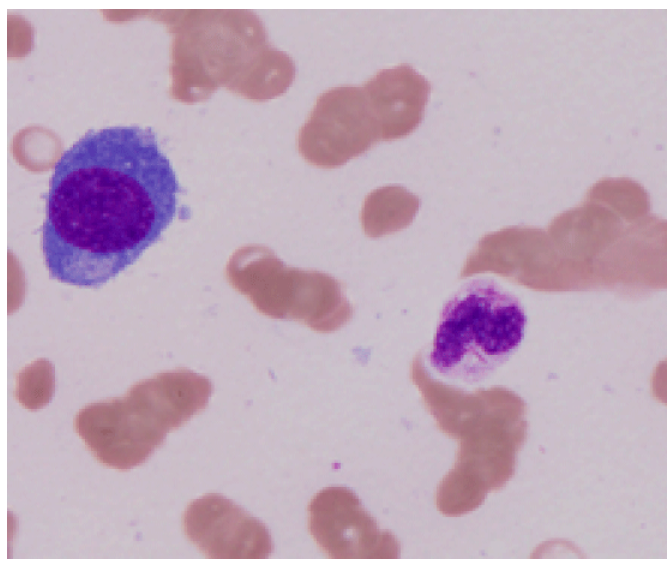

Figure 1: Myeloma cell and neutrophil with prominent Auer rods.

\section{References}

1. Bruns I, Cadeddu RP, Brueckmann I, Fröbel J, Geyh S, et al. (2012) Multiple myeloma-related deregulation of bone marrow-derived CD34+ hematopoietic stem and progenitor cells. Blood 120: 2620-2630. 